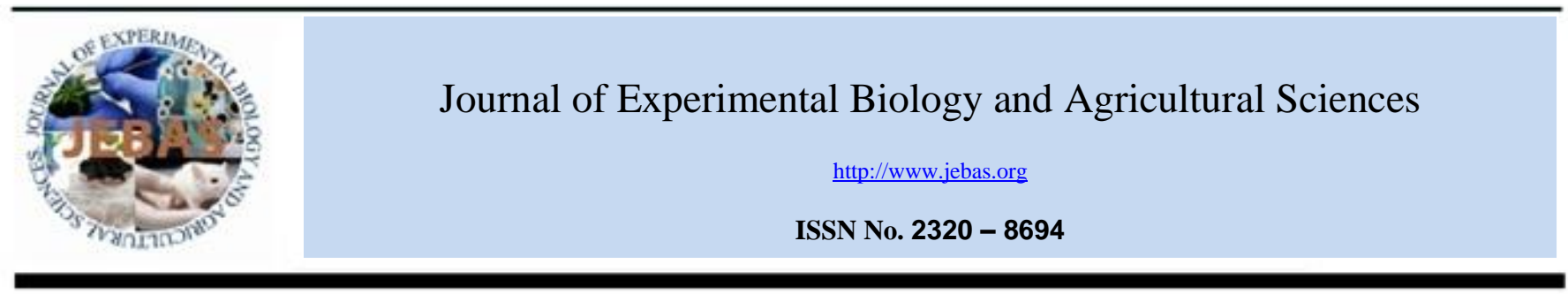

\title{
EFFECT OF DIFFERENT PLANTING DATES AND DEFOLIATION ON THE PROPERTIES OF SUGAR BEET (Beta vulgaris L.)
}

\author{
Mohammad Nabi Ilkaee ${ }^{1, *}$, Zohre Babaei ${ }^{1}$, Amirsaleh Baghdadi ${ }^{1}$ and Farid Golzardi ${ }^{2}$ \\ 1 Department of Agronomy, Karaj Branch, Islamic Azad University, Karaj, Iran \\ 2 Seed and Plant Improvement Institute, Agricultural Research, Education and Extension Organization (AREEO), Karaj, Iran. \\ Received - December 31, 2015; Revision - January 14, 2016; Accepted - January 30, 2016 \\ Available Online - February 20, 2016
}

DOI: http://dx.doi.org/10.18006/2015.4(1).52.58

\begin{abstract}
KEYWORDS
Defoliation stage

Sugar Percentage of Root

Root Yield

White Sugar Yield

ABSTRACT

The experiment was conducted in spring 2014 to evaluate the effect of defoliation on the quantitative and qualitative characteristics of sugar beet in Motahari research station located in the Kamal Shahr region in Karaj, Iran. The study was conducted in split plot factorial with completely randomized block design with four replications. The main factors included two planting dates viz 23 April, 2014 (suitable planting time) and 18 May, 2014 (Late planting) and the sub-factors included five levels of defoliation including stage of early cotyledon growth to two true leaves (2 leaves), the stage of plant deployment (about 12 leaves), mid-growth (about 32 leaves) and late season of growth (about 54 leaves) and another sub-factors included five levels of defoliation intensity of leaves included $25 \%, 50 \%, 75 \%$ and $100 \%$ of defoliation and non-defoliation stage (control) as randomized and factorial were considered. Result of study revealed that different planting dates have significant effect on the sugar percentage of root. In addition, the treatment of defoliation stage could have a significant effect on root yield and white sugar yield $(p>0.01)$. The treatment of defoliation intensity had a significant effect on all three traits $(p>0.01)$. In general, increase in the defoliation intensity negatively affects the root yield and significantly reduced the white sugar yield (compared to control). Among the various stages of defoliation, middle stages of the defoliation have least effect on the evaluated traits which indicated more sensitivity of this treatment during the growing season of plant.
\end{abstract}

* Corresponding author

E-mail: mn64_ilkaee@yahoo.com (Mohammad Nabi Ilkaee)

Peer review under responsibility of Journal of Experimental Biology and Agricultural Sciences.

Production and Hosting by Horizon Publisher (http://publisher.jebas.org/index.html).

All rights reserved.
All the article published by Journal of Experimental Biology and Agricultural Sciences is licensed under a Creative Commons Attribution-NonCommercial 4.0 International License Based on a work at www.jebas.org.

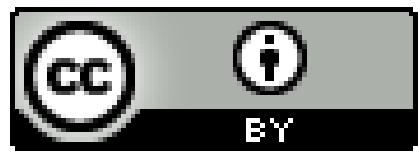




\section{Introduction}

There are several biotic and abiotic factors which able to damage the leaves of sugar beet plants and subsequently reduce the yield. Among these, some of the already noted factors are cold and frost, drought, hail, wind, pests and diseases which can effectively reducing the leaf area (Jadidi et al., 2010). Sugar beet production under semi-arid conditions of growth has been mainly decreased due to the limited access to water (Morillo-Velarde \& Ober, 2006). Water shortage may be a significant limiting factor and can reduce the quality of sugar beet root in the future due to climate changes (Jones et al., 2003). In the Middle East, low rainfall during the months of July and August, when water demand is maximum, supplemental irrigation is necessary to avoid lowering the quality of sugar beet root. Furhter, sugar beet is a drought tolerant species (François \& Maas, 1994) and part of the plant foliage (defoliation) limited the water demand and respond to the environmental stress (Vesk \& Westoby, 2003).

Since the leaves of plants are the main area of receiving sunlight and photosynthetic. Therefore, any reduction in the surface of leaves or their low efficiency can be considered as main factors in reducing the ability of plant to assimilate carbon dioxide and on the other hand decrease the translocation of assimilates into the storage or vegetative organs and subsequently impairs the plant yield. For this reason, the estimation of yield loss caused by defoliation has an important role in farm management (Muro et al., 2001; Ashley et al., 2002;Abdi et al., 2007). Data obtained from the simulated hail damages as defoliation in the United States, Canada, England, India and Spain suggest that damages resulted from hail on the quantity and quality of sugar beet depend on the severity of the damage in stage and period of development (Alimoradi, 2001). Every year pests, diseases and hail caused considerable damage to sugar beet farms in the country. Further, there are no scientific patterns to estimate the damages caused by hail and other factors reducing leaf area in sugar beet farms. Though some effort has been carried out for the estimation of these damages but these are often not accurate. That's why this study was conducted to eastimate the damages caused by hail factors. With this effect of leaf area reduction via defoliation on qualitative and quantitative yield of sugar beet was also determined. The effects of time and intensity of defoliation on root yield and other quantitative and qualitative characteristics of root were also studied. In Montana, Morris (1950) found that complete defoliation in late June or early July in sugar beet reduced yield to a quarter of the normal conditions and $50 \%$ defoliation can reduce yield to one sixth of normal conditions (Morris, 1950). Under similar condtions, Afanasiev et al. (1960) reported that more than $75 \%$ defoliation caused reduction in root yield to less than $6 \%$ and the yield of the plant to less than $20 \%$.

According to the results of the research, complete defoliation caused $80 \%$ reduction in weight of the leaves between $23 \%$ to $27 \%$ decline in the yield of root. In fact, when sugar beet is confronted with semi-arid conditions, high temperature, light and salinity stress is not easily separable and more complex situation is created (Munns, 2002; Chaves et al., 2002). According to the reports of Jones et al. (1955) in the UK on sugar beet, $50 \%, 75 \%$ and $100 \%$ defoliation at 4 or 8 - leaf stages decreased the root yield to 5\%,10\% and $27 \%$, respectively. The results of artificial defoliation at 120 and 144 days after planting in India showed that defoliation treatments of $25 \%, 50 \%$, or $75 \%$ did not reduce the root yield of sugar beet, but $100 \%$ defoliation at 120 days after planting significantly decreased the root yield (Singh et al., 1980). Defoliation to $100 \%$ in late June or early July or middle of September or the middle of October decreased the average root yield in the 3-year period to 23,27, 20 and $10 \%$, respectively (Stallknecht \& Gilbertson, 2000).

\section{Materials and Methods}

The experiment was conducted in Motahari research station located in Kamalshahr of Karaj during 2014. The station is located at Latitude $35^{\circ} 15^{\prime} \mathrm{N}$ and longitude $50^{\circ} 51^{\prime} \mathrm{E}$ with an altitude of about 1300 meters above sea level. This area with 180-150 dry days is considered of the hot and dry Mediterranean climate zones. Split plot factorial experiments were carried out in a randomized complete block design with four replications. Treatments of planting dates as main plots were placed on two levels, including 23 April, (appropriate time of planting) and 18 May, (at late planting ). Treatments of defoliation as sub plots were the early growth of cotyledon to two true leaves (2 leaves), establishment stage (about 12 leaves), middle of growth (about 32 leaves) and the end of the growing season (about 54 leaves) along with five levels of defoliation intensity factors including the removal of 25, 50, 75 and 100 percent of leaves and non-defoliation (control) as factorial and random. Row to spacing was $50 \mathrm{~cm}$ and the length of the rows was $8 \mathrm{~m}$ and each sub-plots had four lines and the final harvest took place taking into consideration marginal effects. The amount and time of use from nutrient elements were imposed based on soil test results. During the growing season, pests and weeds were controlled at critical times. Irrigations time was also determined based on the amount of evaporation between 80 and $90 \mathrm{ml}$ from class A pan. Plant density on the farm was considered about 100 thousand plants per hectare.

Defoliation per plot was treated on the green leaves with at least 75 per cent healthy leaves. Defoliation was imposed using scissors and its intensity was based on experimental treatments on each leaf, independently. During the growing season, the process of light absorption was performed using a radiometer in intervals of 20 days, since the beginning of the treatment. The total numbers of leaves were counted every 15 days to determine the time of treatment in the control plot. The final harvest was simultaneously carried out in all the plots in late October or early November, 2014. In the running time of each treatment, dry weights of leaf, petiole, stem and storage root as well as leaf area were determined at a level of about 1 square 
meter after 4 weeks and at harvest time; and the trend of changes was examined in different treatments. Also root yield, sugar content of root and white sugar yield were measured at the end of the growing season. Sugar content of roots was measured by polarimetry (Kunz et al., 2002). Also, according to the results, the reduction in sugar yield caused by leaf damage was determined in each growth stage. Data obtained from this study was analyzed using SPSS software and ANOVA analysis method and LSD test was used for mean comparison $(\mathrm{P}<0.05)$.

\section{Results and Discussion}

\subsection{Root yield}

According to the results of variance analysis, the root yield of sugar beet was not affected by different planting dates. The main effects of defoliation treatments, defoliation intensity and interaction between planting date and the defoliation was reported on the root yield and these were significantly $\operatorname{different}(\mathrm{P}>0.01)$ to each other (Table 1). Among these, lowest root yield was obtained in the middle stage of growth with an average of 48.10 tons per hectare which showed significant differences compared with other treatments. The highest root yield (57.40 tons per hectare) was also achieved in the early stages of growth (Figure 1). This factor can be attributed to the fact that at the beginning of growth, the pace of growth in many plants is directly associated with the amount of light received by their leaf area (Monteith, 1977; Gallagher \& Biscoe, 1978). In fact, when the plant encounters in the early stages with a treatment of defoliation has more time for the next leaf production and capture more light, resulting in increased yield so that plant is almost associated with higher levels of leaves until the middle stages of growth. Compare the average interaction between planting date and defoliation showed that the highest ratio of root yield was observed in the treatment of early planting date and the initial defoliation stage (64.72 tons per hectare) and the lowest root yield was in the treatment of late planting date and in the middle of the defoliation stage (42.27 tons per hectare) (Figure 3). It is also remarkable that the ratio of root yield was reduced by increasing the intensity of defoliation. So that the highest root yield (61.89 tons per hectare) was obtained in control and the lowest rate (51.05 tons per hectare) was in treatment of $100 \%$ defoliation (Figure 2); it could be due to reduced ability to absorb light by plant with increasing the intensity of defoliation. Result of the present study are in agreement with the findings of Morris (1950,) also found that with increasing the intensity of defoliation, the root yield will be greatly reduced. Further, Afanasiev et al. (1960) reported that complete defoliation led to a reduction of 23 to 27 percent of yield in sugar beet. Similar types of results was obtained by Singh et al. (1980), they suggested that complete defoliation at 120 days after planting can severely reduce root yield; but unlike the results of this study, Singh and colleagues did not observe any reduction in root yield in the treatments of $25 \%$, $50 \%$ and $75 \%$ defoliation. Jones et al. (1955) in their research on sugar beet in the United Kingdom reported that 50\%, 75\% and $100 \%$ defoliation in the 4 and 8-leaf stages decreased root yield, respectively, to $5 \%, 10 \%$ and $27 \%$.

\subsection{Sugar content of root}

According to the results of Table 1, plants that were planted at late planting date had higher sugar content, so that the ratio of these traits showed significant differences compared to the early planting which the ratio in late May planting was $15.16 \%$ while in early planting it was $14.03 \%$ (Figure 4 ). This can be attributed to the fact that, unlike the earlier planted plants, plants that were planted later have spent most of their energy for storage of sugar in the root. In fact, early planting has probably led to more opportunities for more suitable vegetative growth. According to present research, there is a negative correlation between root weight and sugar content in sugar beet was reported by various researchers (Abdollahian Noghabi, 1992; Ashraf Mansouri, 2000; Ebrahimian, 1993; Habibi, 1993; Beigy, 2007; ). Also in the studies of Bazrafshan et al. (2008) highest percentage of sugar in late planting date (25th June) was $14.98 \%$ and $17.72 \%$ on 20th May (Sarmast-Garusi, 2011).

Table 1 Analysis of variance for treatments of planting date, defoliation stage and intensity of defoliation on physiological traits in sugar beet.

\begin{tabular}{l|cccc|} 
Source of variations (S.O.V.) & Degree of Freedom (d.f.) & Root yield & Sugar content of root & White sugar yield \\
\hline Replication & 3 & 439.01 & 1.85 & 4.50 \\
\hline Planting dates(Pd) & 1 & $4058.45^{\mathrm{ns}}$ & $51.05^{*}$ & $15.13^{\mathrm{ns}}$ \\
\hline Error Pd & 3 & 697.07 & 3.03 & 16.62 \\
\hline Defoliation(D) & 3 & $788.96^{* *}$ & $1.47^{\mathrm{ns}}$ & $13.21^{* *}$ \\
\hline Defoliation intensity(Di) & 4 & $714.76^{* *}$ & $2.31^{* *}$ & $14.84^{* *}$ \\
\hline $\mathrm{Pd} \times \mathrm{D}$ & 3 & $198.56^{*}$ & $0.44^{\mathrm{ns}}$ & $2.29^{\mathrm{ns}}$ \\
\hline $\mathrm{Pd} \times \mathrm{Di}$ & 4 & $49.53^{\mathrm{ns}}$ & $0.91^{\mathrm{ns}}$ & $0.31^{\mathrm{ns}}$ \\
\hline $\mathrm{D} \times \mathrm{Di}$ & 12 & $1.02^{\mathrm{ns}}$ & $1.23^{\mathrm{ns}}$ \\
\hline $\mathrm{Pd} \times \mathrm{D} \times \mathrm{Di}$ & 12 & $96.21^{\mathrm{ns}}$ & $1.00^{\mathrm{ns}}$ & $0.96^{\mathrm{ns}}$ \\
\hline Error & 114 & $65.75^{\mathrm{ns}}$ & 0.6 & 1.15 \\
\hline \hline C.V. $(\%)$ & & 66.61 & 5.31 & 16.92 \\
\hline
\end{tabular}

n.s: not significant. *, **: Statistically significant at $\mathrm{P}<0.05,0.01$, respectively. 


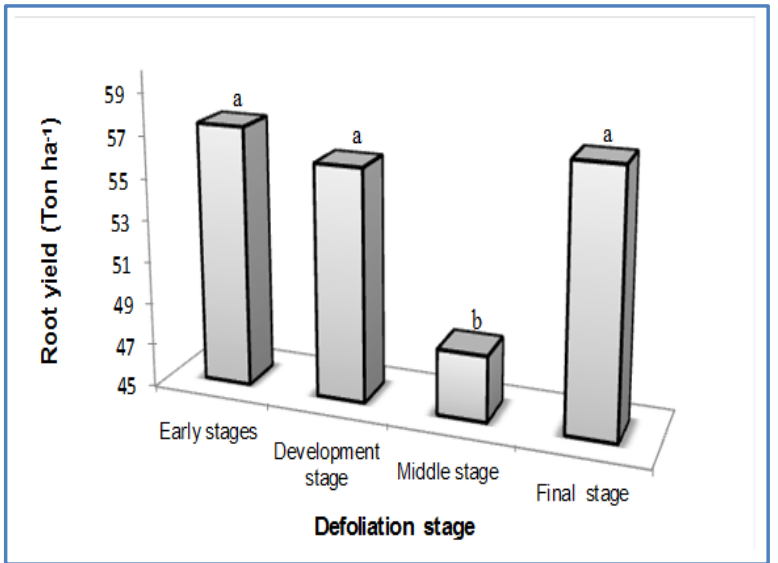

Figure 1 The effect of defoliation stages on root yield of sugar beet

In this regard, have stated that on April planting, the sugar content of root was more compared to late planting date due to the production of larger roots (Chaves et al., 2002). The intensity of defoliation had a significant effect $(\mathrm{P}>0.01)$ on sugar content in roots (Table 1). The most sugar content $(15.04 \%)$ was related to the control and the lowest percentage $(14.35 \%)$ was observed in treatments of $100 \%$ defoliation (Figure 5). According to the table of mean comparisons, there was a significant difference among treatments of control and defoliation. This means that defoliation, reduced sugar content in sugar beet root, but the intensity of defoliation had no significant effect on reducing the traits. The results of these experiments were in agreement with the reports of Kamandi et al. (2008). Also in accordance with the results of SarmastGarusi (2011) in the maximum reduction of sugar content was found in complete defoliation treatment. In this study, sugar content was not affected by the mean defoliation stage. These

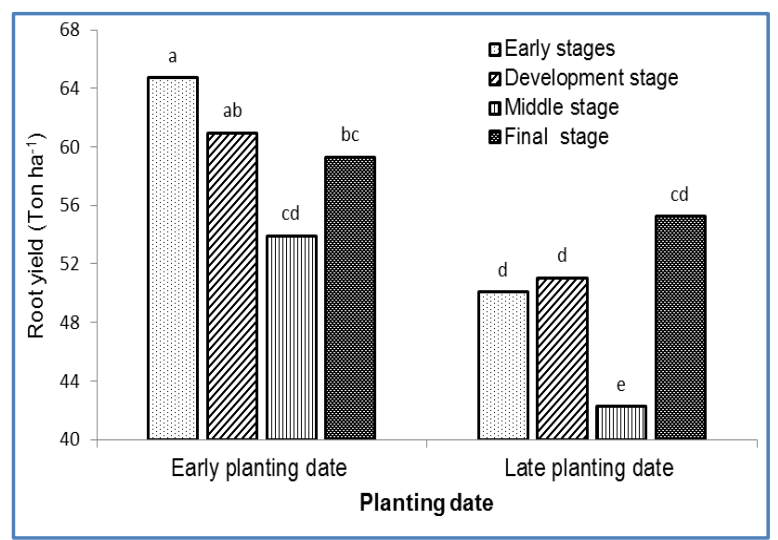

Figure 3 The effect of interaction between treatments of planting date and defoliation stage on root yield of sugar beet

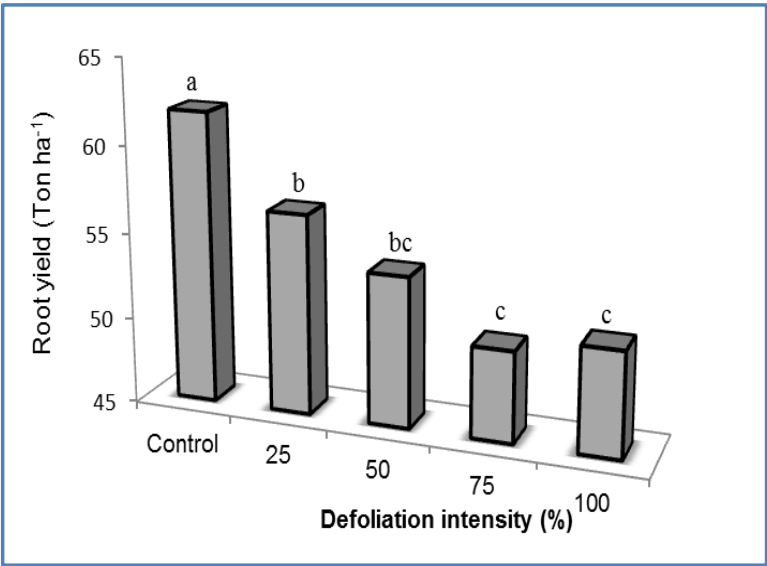

Figure 2 The effect of the intensity of defoliation treatment on root yield of sugar beet

results indicate that plant leaves for their development use the large amount of sugar stored without recycling opportunities.

\subsection{White sugar yield}

According to the results, it can be stated that unlike planting date which had no significant effect on the yield of white sugar, some factors, such as intensity and stages of defoliation caused significant difference $(\mathrm{P}>0.01)$ on this trait (Table 1). Among the intensity of defoliation treatments, the highest yield of white sugar (6.57 tons per hectare) was belonged to $25 \%$ defoliation and the lowest rate (5.88 tons per hectare) was obtained in $100 \%$ defoliation (Figure 7); but generally complete defoliation treatments caused a significant decrease in yield of white sugar compared to the control. In fact, there was an inverse relationship between high intensity of defoliation and white sugar yield that can be attributed due to less absorption of light by leaves.

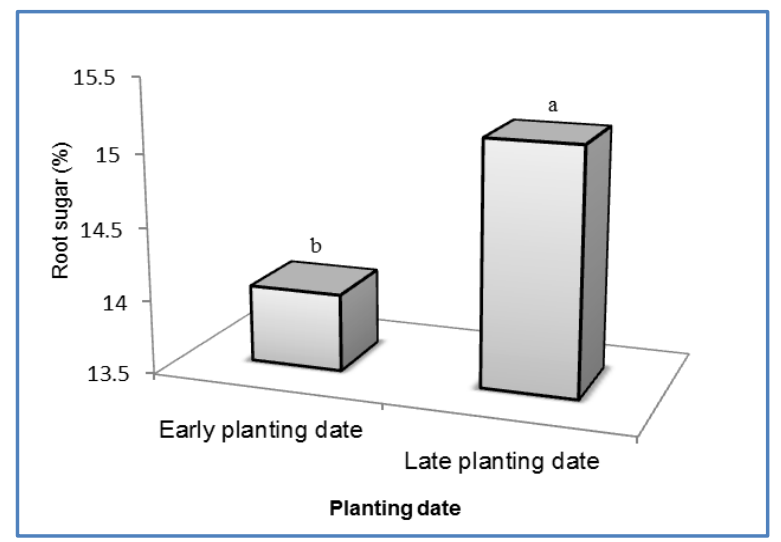

Figure 4- The effect of planting date on the sugar content in sugar beet root 


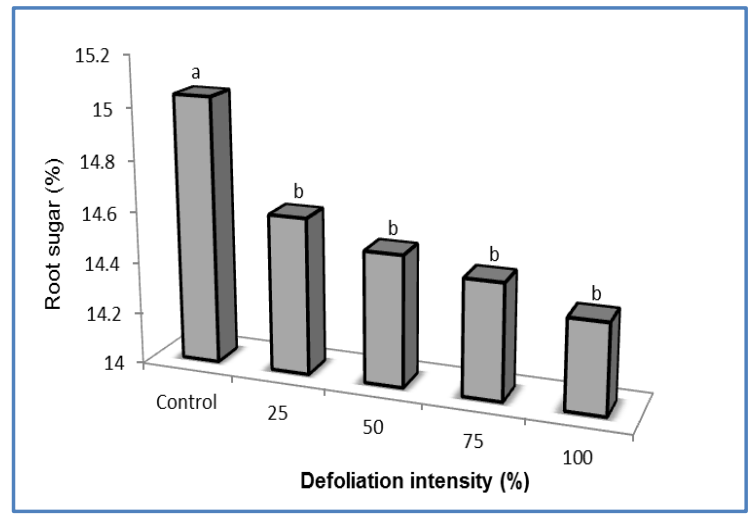

Figure 5- The effect of the intensity of defoliation on the sugar content in sugar beet root

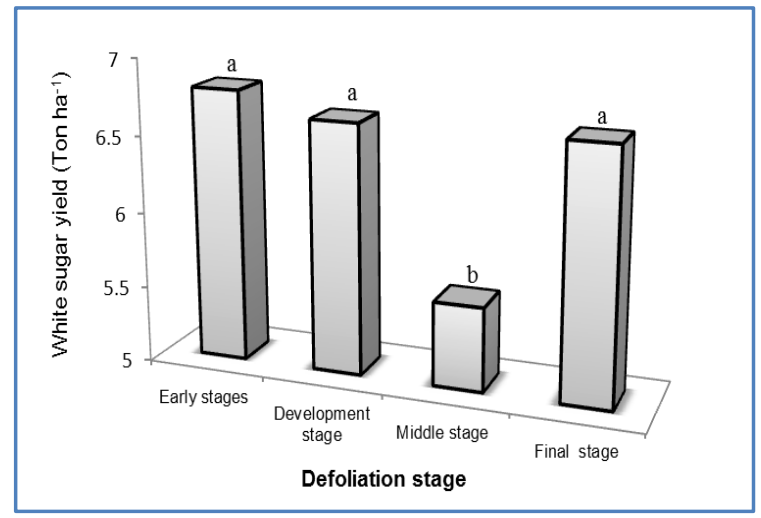

Figure 6- The effect of defoliation stages on the yield of white sugar in sugar beet

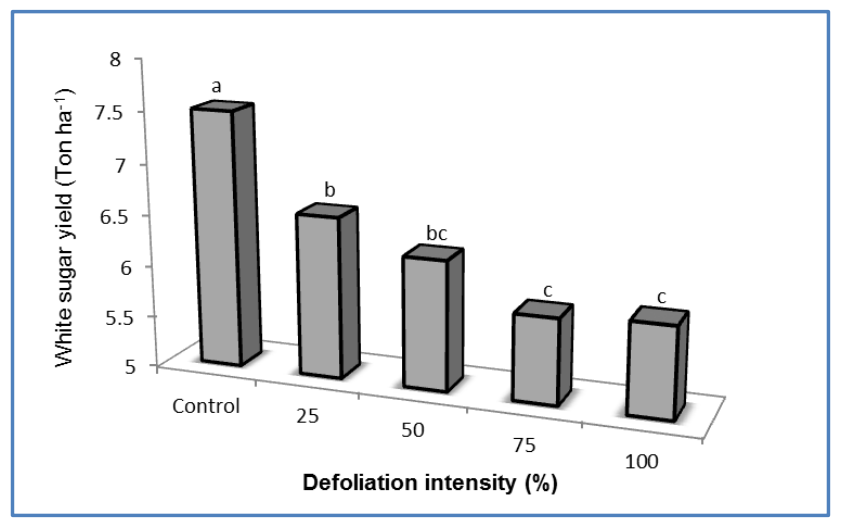

Figure 7- The effect of the intensity of defoliation on the yield of white sugar in sugar beet.

According to Stallknecht \& Gilbertson (2000) 100\% defoliation leads substantially to decrease in the amount of sugar yield. Further, according to the results of Kamandi et al. (2008), white sugar yield was declined with increasing of defoliation compared with the control (non- defoliation). In this study, it was observed that the least amount of white sugar yield was achieved in the middle stage of growth, which this decrease can be expected due to the lowest of produced root yield. The greatest amount of white sugar yield was belonged to the early stage treatments with 6.79 tons per hectare and the lowest rate was observed in the middle stage treatments with 5.55 tons per hectare (Figure 6). According to the results of Muro et al. (1998) in defoliation treatments in the middle of growth had the greatest impact on reducing of root yield and consequently the yield of white sugar.

\section{Acknowledgements}

The authors would like to thank respectable authorities on Motahari research station in Kamalshahr of Karaj, as well as Department of Agronomy, Faculty of Agriculture, Islamic
Azad University of Karaj, Iran that helped me out in carrying out this study.

\section{Conflict of interest}

Authors would hereby like to declare that there is no conflict of interests that could possibly arise.

\section{References}

Abdi S, Fayyaz moghaddam A, Ghadimzade M (2007) Effect of different levels of defoliation in reproductive stages of plant on seed yield and oil content in two varieties of sunflower hybrid. Journal of Science and Technology of Agriculture and Natural Resources 11: 245-255. (In Persian).

Abdollahian Noghabi M (1992) Evaluation of quantitative and qualitative parameters of sugar beet grown in different planting dates. Ms.C. thesis of Agriculture, Faculty of Agriculture, Tarbiat Modarres University, Pp 141-145. (In Persian). 
Afanasiev MM, Lyda SD, Mills IK (1960) Simulated hail injury to sugar beets. American Society of Sugar Beet Technologist 11: 196-200.

Alimoradi I (2001) Effect of defoliation during the growing periods on the yield and quality of sugar beet. Journal Iranian Sugar Industry 15: 311-318. (In Persian).

Ashley RO, Eriksmoen ED, Whitney MB, Rettinger B (2002) Sunflower date of planting study in Western North Dakota. Annual Report, Dick. Rest Extension, Pp 48.

Ashraf Mansouri GH (2000) The effect of planting date and plant density on root and sugar yields in two cultivars of sugar beet in Darab region. Iranian Crop Science Congress. Mazandaran University. Babolsar, Iran. (In Persian).

Bazrafshan M, Taleghani DF, Sharifi H, Ghaemi A, Baghaee Kia M (2008) Determine the best planting and harvesting date of new varieties of sugar beet monogerm hybrid. The final report of the research project. Sugar Beet Seed Improvement Institute. (In Persian).

Beigy S (2007) Effect of planting date of density in two plants and cultivar on light absorption and quantitative and qualitative yield in sugar beet. MSc thesis of Agriculture, Faculty of Agriculture in Islamic Azad University of Karaj, Pp 120-124. (In Persian).

Chaves MM, Pereira JS, Maroco J, Rodrigues ML, Ricardo CPP, Osório ML, Carvalho I, Faria T, Pinheiro C (2002) How plants cope with water stress in field: photosynthesis and growth. Annals of Botany 89: 907-916. doi: 10.1093/aob/mcf105.

Ebrahimian HR (1993) The effect of planting date and period of growing season on sugar beet. Proceedings of the First International Congress of Plant Breeding Iran, Karaj, Pp 130131. (In Persian).

Francois LE, Maas EV (1994) Crop response and management on salt-affected soils. In: Pessarakli M. (Ed.), Handbook of Plant and Crop Stress. Marcel Dekker Inc., New York, Pp 149181.

Gallagher JN, Biscoe PV (1978) Radiation absorption, growth and yield of cereals. Journal of Agricultural Science 91: 47-60. http://dx.doi.org/10.1017/s0021859600056616.

Habibi D (1993) Selection of resistant progenies to drought and salinity in the early germination stage. Ms.C. thesis of Agriculture, Faculty of Agriculture, Islamic Azad University of Karaj, Pp 154-156. (In Persian).

Jadidi T, Hejjam Y, Kamali GHA, Fotouhi K, AbdollahianNoghabi M (2010) Effect of defoliation intensity at different growth stages on the root yield and quality of sugar beet. Iranian Journal of Crop Sciences 12: 255- 264. (In Persian).

Jones FGW, Dunning RA, Hamphries KP (1955) The effect of defoliation and loss of stand upon yield of sugar beets. Annals of Applied Biology 43: 63-70. http://dx.doi.org/10.1111/j.1744-7348.1955.tb02453.x.

Jones PD, Lister DH, Jaggard KW, Pidgeon JD (2003) Future climate impact on the productivity of sugar beet (Beta vulgaris L.) in Europe. Climate Change 58: 93-108. doi: 10.1023/A:1023420102432.

Kamandi A, Nezami A, Kucheki A, Nassiri Mahallati (2008) Effect of defoliation on quantitative and qualitative yield of sugar beet in Mashhad. Iranian Journal of Crop Researches 6: 371-381. (In Persian).

Kunz M, Martin D, Puke H (2002) Precision of beet analyses in Germany explained for polarization. Zuckerindustrie 127: $13-21$.

Monteith JL (1977) Climate and the efficiency of crop production in Britain. Philosophical transactions of the Royal Society of London B 281: 277-297. DOI: 10.1098/rstb.1977.0140.

Morillo-Velarde R, Ober ES (2006) Water use and irrigation. In: Draycott PA (Ed.), Sugar Beet. Blackwell Publishing Ltd, Oxford, Pp 221-255. http://dx.doi.org/10.1002/9780470751114.ch10.

Morris HE (1950) Simulated hail damage to sugar beets 194849. American Society of Sugar Beet Technology 6: 302-304.

Munns R (2002) Comparative physiology of salt and water stress. Plant, Cell \& Environment 25: 239-250. http://dx.doi.org/10.1046/j.0016-8025.2001.00808.x.

Muro J, Irigoyen I, Lamsfus C (1998) Defoliation timing and severity in sugar beet. Agronomy Journal 90: 800-804. http://dx.doi.org/10.2134/agronj1998.00021962009000060014 $\mathrm{x}$.

Muro J, Irigoyen I, Milition M, Lamsfus C (2001) Defoliation effects on sunflower yield reduction. Agronomy Journal 93: 634-637. http://dx.doi.org/10.2134/agronj2001.933634x.

Sarmast Garusi A (2011) Effects of intensity and period of leaf area reduction at two date of planting on phenology and yield of sugar beet. Ms.C. thesis of Agriculture, Faculty of Agriculture, Islamic Azad University of Roodehen, Pp 121123. (In Persian) . 
Singh KN, Sachan GC, Chhibber RC (1980) Effect of artificial defoliation on root and sucrose yield of sugarbeet. Indian Sugar 29:715-718.

Stallknecht GF, Gilbertson KM (2000) Defoliation of Sugarbeet: Effect on Root Yield and Quality. Journal of
Sugare

Beet

Research

$37: 1-10$.

http://dx.doi.org/10.5274/jsbr.37.2.1.

Vesk PA, Westoby M (2003) Drought damage and recovery-a conceptual model. New Phytologist 160: 7-14. http://dx.doi.org/10.1046/j.1469-8137.2003.00887.x. 